\title{
PERLINDUNGAN TERHADAP BENDA CAGAR BUDAYA PATUNG SEPUNDU SEBAGAI WARISAN BUDAYA
}

\author{
Mulida Hayati ${ }^{1^{*}}$ \\ ${ }^{1}$ Universitas Palangka Raya, Indonesia \\ *e-mail: mulida.fh.upr@gmail.com
}

\begin{abstract}
Abstrak
Tujuan dari penelitian ini untuk mengetahui bentuk perlindungan terhadap benda cagar budaya terutama patung sepundu menurut Hukum Positif dan Hukum Adat untuk menjaga warisan budaya. Metode penelitian yang dipergunakan adalah penelitian yuridis normatif. Metode pendekatan dilakukan dengan dua cara yakni pendekatan Undang- undang (Statute approach), Metode Pendekatan Kasus (case approach). Hasil penelitian menunjukkan bahwa Perlindungan dari KUHP khususnya dalam Pasal 363 tersebut sifatnya berbentuk preventif dan represif, dalam Undang-undang Republik Indonesia Nomor 11 Tahun 2010 tentang Cagar Budaya, Pasal 26,27,28 dan 66. Upaya perlindungan secara preventif dan dengan secara represif, upaya preventif dilakukan dengan memberikan penyuluhan hukum kepada masyarakat. Sementara upaya represif dilakukan dengan pemberi Sanksi Adat bagi perbuatan mencuri tersebut dapat dikenakan Singer (denda), yaitu: Singer rampas takau luar huma (denda adat curi-rampas barang di luar rumah), dengan penjelasannya: Barang milik orang di luar rumah hilang di curi orang lain, pemiliknya memberitahukan kehilangan itu kepada Ketua Adat setempat, walaupun waktu itu tidak diketahuisiapa yang berbuat, tetapi kemudian diketahui hal ini langsung dituntut. Sanksinya: Pencuri diancam hukuman 15-30 kati ramu (barang adat), dapat ditambah kalau nilai barang itu tinggi dan sisa barang itu sengaja dirusaki. Dapat diringankan kalau barang itu dikembalikan sebagian atau seluruhnya dalam keadaan baik, ditutup dengan pesta adat yang ditanggung oleh pihak pencuri.
\end{abstract}

Kata kunci: Perlindungan; Patung Sepundu; Warisan Budaya

\begin{abstract}
According to Positive Law and Customary Law, the purpose of this study was to determine the form of protection for cultural heritage objects, especially Sepundu Statues, to protect cultural heritage. The research method used is normative juridical research. The approach method is carried out in two ways, namely the statute approach and the case approach. The results show that the Criminal Code's protection, especially in Article 363, is preventive and repressive, in Law of the Republic of Indonesia Number 11 of 2010 concerning Cultural Heritage, Articles $26,27,28$, and 66. Preventive and repressive protection measures, preventive efforts are made by providing legal education to the public. Meanwhile, repressive efforts are carried out by providing Customary Sanctions for the act of stealing, which can be subject to Singer (fines),
\end{abstract}


namely: Singer seizing takau outside the home (customary fines for stealing goods outside the home), with the explanation: Property belonging to people outside the house is lost in stolen. Another person, the owner, notified the loss to the local customary chief. Although it was not known who did this, it was found out that this was immediately prosecuted. The penalty: Thieves are threatened with a penalty of 15-30 kati ramu (customary goods). This can be added if the goods' value is high and the rest of the goods is deliberately damaged. It can be alleviated if the goods are returned partly or entirely in good condition, closed with a traditional party borne by the thief.

Keywords: Protection; Sepundu Statue; Cultural Heritage

This is an open access article under the CC BY-SA license.

Copyright (C) 2021 by Author. Published by Universitas Pendidikan Ganesha.

\section{PENDAHULUAN}

Bangsa Indonesia dikenal banyak mewarisi kebudayaan daerah yang demikian kaya dan beraneka ragam. Hal ini terbukti dari sejarah perkembangan Bangsalndonesia dalam pencapaian kreasi dan karya budaya yang sampai sekarang masih mengundang kekaguman dari Bangsa Asing (Suarta, 2013). Namun banyaknya kebudayaan daerah itu tidak semuanya dengan mudah dapat dikenali dengan baik, karena penyebarannya yang meluas di seluruh nusantara (Syamsuddin, 2018).

Pola hidup dan karya dari masyarakat tertentu tidak harus selalu sama dengan masyarakat lain, dalam sudut pandang etnik (Hartoyo, 2012). Hal ini perlu disadari dan dipahami, karena terbentuknya suatu komunitas manusia berawal dari komunitas etnik atau suku, sehingga dalam pola hidup kesukuan selalu ada perbedaanperbedaan tertentu sebagai ciri khas antara suku yang satu dengan yang lainnya (Yunus \& Fadli, 2020). Peristiwa-peristiwa sejarah dari masyarakat masa lampau itu dapat diteliti dan dihimpun berdasarkan data atau bukti-bukti, baik yang berupa buktibukti tertulis maupun yang tidak tertulis. Bukti-bukti itulah yang seringkali disebut sumber sejarah yang jenisnya bermacam-macam. Bukti-bukti tersebut dapat pula kita namakan peninggalan sejarah dalam arti yang luas dengan aspek yang terkandung padanya, mengingat bukti-bukti atau peninggalan sejarah tersebut dapat mengandung aspek sosial, politik, ekonomi, agama dan kebudayaan (Djulianto, 2016).

Salah satunya ciptaan nenek moyang Suku Dayak adalah Hampatung (patung) hasil ciptaan Leluhur Suku Dayak di Kalimantan Tengah. Hampatung yang dibuat beraneka ragam dengan bentuk dan keunikan yang menarik perhatian. Hal demikian banyak ditemukan terutama pada motif khas hampatung menurut versi suku Dayak di Kalimantan Tengah. Motif tersebut biasanya banyak digali dari hasil kebudayaan dayak dan erat berkaitan dengan mitologi Kepercayaan Keharingan yang sekarang dan banyak lebih bersifat sakral serta mempunyai nilai filosofis yang tinggi.Salah satu bentuk hampatung adalah sepundu, asal 
mula sepundu adalah karena dengan adanya acara tiwah bagi masyarakat yang beragama hindukaharingan maka mereka membuat sapundu sebagai simbol dan tempat mengikat binatang korban untuk upacara tiwah tersebut untuk mengantar roh yang di tiwah menuju lewu tatau. Jadi persisnya kapan asal mula maka yang kami tahu sejak adanya Agama Hindu Kaharingan di Kalimantan tengah maka sapundu itu ada dalam hal untuk kami mengikat binatang korban buat acara tiwah berupa sapi atau kerbau (Lion, 2020). Istilah peninggalan budaya dijabarkan secara luas oleh Undang-Undang Nomor 11 Tahun 2010 Tentang Cagar Budaya. Ironisnya, manakala ada produk hukum untuk melindunginya, semakin sering orang-orang tidak bertanggung jawab yang melakukan kejahatan terhadapnya.

Menurut Lewi Naya, Mantir Adat

Desa Bukit Batu, Kecamatan Cempaga Hulu Kabupaten Kotawaringin Timur, pada prinsipnya kejahatan terhadap peninggalan budaya terbagi dalam enam kasus, yakni: pencurian, penyelundupan, penyingkiran, penggusuran, penggalian liar, dan perusakan. Kasus yang paling banyak adalah pencurian, sebenarnya pencurian terhadap peninggalan-

peninggalan purbakala sudah terjadi sejak masa pra- kemerdekaan, sebagaimana identifikasi secara administrasi sejak tahun 1960-an (Lion, 2020). Menyimak lebih dalam fenomena dibalik pencurian Patung Sapundu pada tahun 2015, 2 (dua) buah Sapundu pernah dinyatakan hilang dari tempatnya, yaitu di Desa Bukit Batu, Kecamatan Cempaga Hulu,
Kabupaten Kotawaringin Timur, Provinsi Kalimantan Tengah.

Peristiwa di atas hanyalah salah satukasus diantara sekian banyak kasus pencurian benda cagar budaya yang terjadi di Provinsi Kalimantan Tengah. Seperti diketahui Sapundu keberadaannya sangat sakral dan berhubungan erat dengan keimanan, ketakwaan, serta keyakinan dan kepercayaan Umat Hindu Kaharingan.Ada sejumlah motivasi mengapa masyarakat melakukan kejahatan terhadap benda- benda budaya (Safitrf, 2013). Motivasi yang paling utama adalah mencari keuntungan sebesar-besarnya (faktor ekonomi), dengan melakukan pencurian, penggalian liar, dan penyelundupan mereka mengharapkan hasil tinggi dari penjualan benda-benda itu. Motivasi berikutnya adalah kepercayaan terhadap sesuatu yang sakral, sehingga orang mengiginkan benda tersebut sebagai koleksi pribadi

peninggalan arkeologis (Djulianto, 2016).

Beragam wujud warisan budaya lokal memberi kita kesempatan untuk mempelajari kearifan lokal dalam mengatasi masalah-masalah yang dihadapi dimasa lalu. Masalahnya kearifan lokal tersebut seringkali diabaikan, dianggap tidak ada relevansinya dengan masa sekarang apalagi masa depan (Onibala, 2017). Dampaknya adalah banyak warisan budaya yang sudah lapuk dimakan usia, terlantar, terabaikan bahkan dilecehkan keberadaannya. Padahal banyak bangsa yang kurang kuat sejarahnya justru mencari-cari jati dirinya dari peninggalan sejarah dan warisan budayanya yang sedikit jumlahnya 
(Sutanto, 2014). Kita sendiri Bangsa Indonesia yang kaya dengan warisan budaya justru mengabaikan aset yang tidak ternilai tersebut, Sungguh kondisi yang kontradiktif.Sebagai bangsa dengan jejak perjalanan sejarah yang panjang sehingga kaya dengan keanekaragaman budaya lokal seharusnya dapat melestarikan warisan budaya (Hardiyanto, 2017). Melestarikan tidak berarti membuat sesuatu menjadi awet dan tidak mungkin punah, melestarikan berarti memelihara untuk waktu yang sangat lama (Mubarat \&Junoko, 2020).

Upaya pelestarian warisan budaya lokal berarti upaya memelihara warisan budaya lokal untuk waktu yang sangat lama, maka perlu dikembangkan pelestarian sebagai upaya yang berkelanjutan (sustainable) (Karmadi, 2007). Melihat kejahatan terhadap peninggalan benda cagar budaya, maka dirasa perlu mendapat perhatian dan upaya yang serius dari pihak yang terkait dan masyarakat sendiri dalam upaya penanggulangannya. Dalam upaya memelihara dan melestarikan kebudayaan merupakan tanggung jawab bersama, sehingga keberadaan benda-benda peninggalan budaya tersebut tidak punah dan tetap menjadi warisan budaya dari nenek moyang yang patut kita banggakan.

\section{METODE}

$$
\text { Metode }
$$

penelitian yang dipergunakan adalah penelitian yuridis normatif. Metode pendekatan Undang- undang (Statute approach), yaitu: Penelitian yang menekankan pada data primer dan data sekunder yakni dengan mempelajari dan mengkaji asas-asas, bahan-bahan dan kaidah-kaidah hukum positif yang berasal dari bahan-bahan kepustakaan yang ada dalam peraturan perundang-undangan. Sedangkan Metode Pendekatan Kasus (case approach), adalah: Penelitian yang melihat kasus-kasus / peristiwa hukum yang terjadi dalam masyarakat, sebagai data pendukung dalam penulisan penelitian.

\section{HASIL DAN PEMBAHASAN \\ Upaya Penanggulangan Pencurian Benda Cagar Budaya Patung Sepundu}

\section{Upaya dari Pihak Kepolisian}

Secara lebih terperinci Gerson W. Bawengan membagi tugas Polisi, sebagai berikut:

1) Tugas preventif; berupa patrolipatroli yang dilakukan secara terarah dan teratur, mengadakan tanya jawab dengan orang lewat, termasuk usaha pencegahan atau pelaksanaan tugas preventif, memelihara ketertiban dan dam menjamin keamanan umum.

2) Tugas represif; menghimpun buktibukti sehubungan dengan pengusutan perkara dan bahkan berusaha untuk menemukan kembali barang-barang hasil curian, melakukan penahanan untuk kemudian diserahkan ke tangan Kejaksaan yang kelak akan meneruskan ke pengadilan (Soekanto,1988).

Pada dasarnya Polisi preventif ini melakukan tugas-tugas umum Kepolisian yang luas sekali. Sedangkan tugas-tugas represif adalah tugas-tugas Kepolisian yang bersifat menindak 
terhadap para pelanggar hukum untuk diproses dalam S.P.P. sesuai dengan ketentuan-ketentuan hukum yang berlaku baik didalam KUHAP maupun peraturan perundangundanganlainnya (Faal, 1991).

Menurut Iptu Rahmat Tuah Kapolsek Cempaga, beliau mengatakan upaya dari pihak kepolisian dalam menanggulangi pencurian Benda Cagar Budaya, yaitu:

1) Melakukan tugas pokok Kepolisian.

2) Memberikan pengarahan kepada penjaga Benda Cagar Budaya, agar melakukan tugasnya dengan baik dan lebih ditingkatkan dalam hal pengawasan terhadap Benda Cagar Budaya yang dipercayakan pemerintah kepadanya.

3) Melakukan patroli keliling di wilayah hukum masing-masing daerah, dalam rangka melakukan tindakan preventif terhadap semua kemungkinan.

4) Menghimbau kepada masyarakat untuk lebih meningkatkan sadar budaya dan menghargai benda budaya yang syarat dengan nilainilai budaya tersebut, dengan ikut aktif menjaga, memelihara danmelestarikannya.

5) Melakukan penyuluhan hukum dengan berbagai topik permasalahan, dengan adanya kegiatan tersebut akan meningkatkan kesadaran masyarakat akan tertib hukum dalam kehidupannya sehari-hari.

6) Melakukan koordinasi dengan pihak Kejaksaan dan Pengadilan agar pelaku dituntut dengan hukuman yang sepantasnya dengan perbuatannya sehingga akan menimbulkan efek jera.

\section{Upaya Pemerintah Daerah}

Menurut Ahmad, Kepala Desa Bukit Batu Kecamatan Cempaka Upaya pemerintah dalam hal melindungi, memelihara, melestarikan serta menanggulangi pencurian benda cagar budaya ini dapat dilihat dari berbagai upayayang telah dilakukan, antara lain:

1) Mengangkat juru pelihara benda cagarbudaya;

2) Memberikan insentif kepada juru pelihara benda cagar budaya, dengan demikian dapat memotivasi untuk lebih giat menjaga keberadaan benda cagar budaya tersebut;

3) Memantau keberadaan benda cagar budaya tersebut dan menjalankan instruksi dari pusat apabila ada instruksi untuk pemugaran dan sebagainya;

4) Menempatkan papan pengumuman di lokasi benda cagar budaya tersebut yang berisikan himbauan dan larangan seperti ketentuan dalam Undang- undang tentang Benda Cagar Budaya;

5) Membuat pagar pembatas lokasi Benda Cagar Budaya, dengan demikian akan dapat meminimalisir perusakan dan pencurian oleh orang yang tidak bertanggung jawab;

6) Melakukan monitoring yang mana bekerjasama dengan pemerintah pusat dalam hal pendanaan kegiatan tersebut;

7) Apabila terjadi pencurian maka kasus tersebut akan dilaporkan kepada pihak yang berwajib/Kepolisian melalui juru rawat Benda Cagar Budaya 
tersebut atau masyarakat setempat;

8) Memfasilitasi kegiatan kesenian daerah pada event-event regional, nasional, internasional sebagai upaya pembinaan kesenian daerah;

9) Melaksanakan pelestarian benda cagar budaya dan pengembangan kawasan cagar budaya;

10) Mengembangkan benda cagar budaya dan kawasan cagar budaya sebagai pusat penelitian serta aktifitas sosial budaya masyarakat.

Dalam hal memelihara, melestarikan dan menanggulangi segala bentuk kejahatan terhadap benda cagar budaya ini tidaklah cukup apabila tidak ada partisifasi dari masyarakat umum khususnya masyarakat sekitar benda cagar budaya tersebut.

\section{Upaya dari Damang Kepala Adat dan Tokoh Masyarakat}

Upaya yang dapat dilakukan dalam hal menanggulangi pencurian benda cagar budaya menurut nara sumber Barthel Liwan, Damang Kecamatan Bukit Batu, antara lain:

1) Melakukan pengawasan terhadap benda cagar budaya tersebut agar terhindar dari pengrusakan dan perbuatan orang yang tidak bertanggung jawab (pencurian);

2) Memberikan himbauan kepada masyarakat sekitar kawasan benda cagar budaya tersebut agar turut serta menjaga dan melestarikannya;

3) Memberikan arahan dan mengingatkan kepada penjaga benda cagar budaya/ahli warisnya agar dalam menjalankan tugasnya dengan baik dan selalu waspada;Apabila terjadi pencurian benda cagar budaya Ini maka pihak kedemangan akan menindak berdasarkan laporan dari pihak korban, apabila pelaku tertangkap dan diserahkan ke kedemangan maka pelaku tersebut diberikan sanksi hukum adat seperti yang tertuang dalam hukum adat setempat;

4) $\mathrm{Di}$ samping memberikan sanksi hukum adat pelaku juga diserahkan kepada pihak yang berwajib/Kepolisian untuk mempertanggung jawabkan perbuatannya, hal tersebut untuk memenuhi hukum nasional di samping hukum adat yang telah dijatuhkan (tergantung dari pihak korban).

Upaya-upaya di atas merupakan bentuk kepedulian terhadap keberadaan benda cagar budaya, walau bagaimanapun pesan serta dari berbagai pihak sangatlah diperlukan agar benda cagar budaya ini tetap lestari dan berkelanjutan.

\section{Upaya Pemerintah dalam Memberikan Perlindungan Hukum Terhadap Benda Cagar Budaya}

Perlindungan dari KUHP (Kitab UndangUndang Hukum Pidana)

Bentuk perlindungan terhadap benda cagar budaya tersebut seperti hasil dari penelitian penulis yaitu melalui penerapan Pasal 363 KUHP. Perlindungan dari KUHP khususnya dalam Pasal 363 tersebut sifatnya berbentuk preventif dan represif. Hal demikian dapat dikatakan dilihat dari 
makna dan tujuan pasal tersebut, preventif disini dengan adanya pasal dalam KUHP tersebut dengan maksud untuk mengendalikan niat dari pelaku untuk melakukan pencurian, dengan diketahuinya pasal tersebut yang pada intinya melarang dan mengancam segala bentuk perbuatan mencuri, maka dengan harapan niat dan perbuatan tersebut dapat digagalkan.

Sedangkan represif yaitu bagaimana apabila terjadi pencurian sehingga menimbulkan kerugian bagi pihak korban maka pasal dalam KUHP ini pula yang dapat dijadikan pedoman untuk menindak atas perbuatan pelaku.

\section{Perlindungan dari Undang-Undang Nomor 11 Tahun 2010 Tentang Cagar Budaya}

Undang-undang Republik
Indonesia Nomor 11 Tahun 2010 tentang Cagar Budaya beserta peraturan pelaksanaannya, maka setiap tindak pidana terhadap benda cagar budaya ada sanksi hukumnya. Undang- undang ini secara khusus mengatur dan melindungi keberadaan benda cagar budaya yang ada di seluruh nusantara ini, maka dalam undang-undang ini telah dijelaskan berbagai hal dengan tujuan sematamata melindungi keberadaan benda cagar budaya sehingga upaya pemeliharaan dan pelestariannya dapat tetap berlanjut.

Bentuk perlindungan dari Undang-undang ini dapat digambarkan melalui Undang-Undang Republik Indonesia Nomor 11 Tahun 2010 tentang Cagar Budaya, yaitu:

Pasal 66:

(1) Setiap orang dilarang merusak Cagar Budaya, baik seluruh maupun bagian-bagiannya, dari kesatuan,kelompok, dan/atau dari letak asal.

(2) Setiap orang dilarang mencuri Cagar Budaya, baik seluruh maupun bagian-bagiannya, dari kesatuan, kelompok, dan/atau dari letak asal.

Kebijakan hukum pidana dalam upaya pencegahan dan penanggulangan tindak pidana terhadap BCB sudah diawali sejak mass penjajahan Belanda, yaitu Monumenten Ordonnantie/M. O 1931 (Stbl. No. 238 Tahun 1931). Namun M.O ini kemudian diganti dengan Undang-Undang Republik Indonesia Nomor 11 Tahun 2010 tentang Cagar Budaya.

Adapun ketentuan pidananya adalah Pasal 26: "Sengaja merusak benda cagar budaya dan situs serta lingkungannya atau membawa, memindahkan, mengambil, mengubah bentuk dan/atau warna, memugar, atau memisahkan tanpa izin dari Pemerintah dipidana dengan pidana penjara selama-lamanya 10 tahun dan/atau dendasetinggi-tingginya $\mathrm{Rp}$ 100.000.000."

Pasal 27: "Sengaja melakukan pencarian benda cagar budaya atau benda berharga yang tidak diketahui pemiliknya dengan cara penggalian, penyelaman, pengangkatan, atau dengan cara pencarian lainnya tanpa izin dari Pemerintah dipidana dengan pidana penjara selama-lamanya 5 tahundan/atau denda setinggi-tingginya Rp. 50.000.000."

Pasal 28 : "Tidak mendaftarkan pemilikan, pengalihan hak dan pemindahan tempat, tidak melapor atas hilang dan/atau rusaknya benda cagar budaya, tidak melapor atas penemuan 
atau mengetahui ditemukannya benda cagar budaya atau benda yang diduga sebagai benda cagar budaya atau benda berharga yang tidak diketahui pemiliknya, memanfaatkan kembali benda cagar budaya yang tidak sesuai dengan fungsinya semula dan menggandakan tanpa seizin Pemerintah; messing-messing dipidana dengan pidana kurungan selama- lamanya 1 tahun dan/atau denda setinggi-tingginya $\mathrm{Rp}$. 10.000.000."

Dengan penjelasan di atas berikut segala ketentuan dalam pasal Undang-Undang Cagar Budaya ini cukuplah menggambarkan bahwa keberadaan benda cagar budaya ini begitu sangat diperhatikan oleh pemerintah dalam usaha untuk melindungi sehingga benda cagar budaya ini tetap dapat lestari dan berkelanjutan.

Perlindungan dari Hukum Adat

Hukum Adat memberikan perlindungan terhadap benda/barang berharga yang menjadi hak milik seseorang,(Hanum \& $\mathrm{SH}, 2013$ ) sama halnya dengan benda cagar budaya patung sapundu ini yang merupakan barang adat suatu upacara adat Tiwah. Setiap perbuatan mencuri bagi masyarakat yang masih menggunakan hukum adat ini akan diberlakukan.

Dalam upaya penanggulangan pencurian patung patung sapundu di Desa Bukit Batu, pihak Desa menempuh dengan upaya secara preventif dan dengan secara represif. Sanksi adat yang bersifat preventif antara lain dapat dilakukan melalui proses sosialisasi. Dalam sosialisasi, nasihat, anjuran, larangan atau perintah dapat disampaikan sehingga terbentuklah kebisaan yang disenangi untuk menjalankan peran sesuai dengan yang diharapkan. Selain itu penyuluhan hukum tersebut bertujuan untuk meningkatkan kesadaran hukum masyarakat agar masyarakat mengtahui bahwa hukum menjanjikan perlindungan dan memajukan kesejahteraan yang selanjutnya mereka akan menikmati keuntungan berupa perlindungan dan kesejahteraan tersebut. Sehingga masyarakat dapat turut serta berperan aktif dalam upaya penanggulangan premanisme. Selain dengan upaya preventif, pihak Desa Bukit Batu juga menempuh upaya represif untuk menindak aksi-aksi pencurian yang terjadi di masyarakat. Sanksi adat yang bersifat represif adalah sanksi adat yang ditujukan untuk memulihkan keadaan seperti sebelum pelanggaran itu terjadi. Sanksi adat ini dilakukan setelah orang melakukan suatu tindakan penyimpangan sosial di lingkungan masyarakat. Sanksi Adat yang bersifat represif bisaanya diikuti dengan penjatuhan sanksi bagi pelaku penyimpangan sosial.

Menurut narasumber Bapak Lewi Naya Mantir Adat Desa Bukit Batu. Apabila terjadi kasus pencurian maka bagi pelaku dapat dikenakan sanksi sebagaimana yang termuat dalam Hukum Adat Suku Dayak.Sanksi bagi perbuatan mencuri tersebut dapat dikenakan Singer (denda), yaitu : Singer rampas takau luar huma (denda adat curi-rampas barang di luar rumah), dengan penjelasannya :Barang milik orang di luar rumah hilang di curi orang lain, pemiliknya memberitahukan kehilangan itu kepada Ketua Adat setempat, walaupun waktu itu tidak diketahui siapa yang berbuat, tetapi kemudian diketahui hal ini langsung dituntut. Sanksinya: Pencuri diancam hukuman 15-30 kati ramu (barang adat), dapat ditambah kalau nilai barang itu tinggi dan sisa barang itu sengaja dirusaki. Dapat diringankan kalau barang itu dikembalikan sebagian atau seluruhnya dalam keadaan baik, ditutup dengan pesta adat yang ditanggung oleh pihak pencuri.

Dapat dikenakan pada pelaku 
pencurian Patung Sapundu yang keberadaan benda tersebut di luar rumah yang merupakan kepunyaan ahli waris dan masyarakat setempat mengingat statusnya sebagai yang sebagai benda cagar budaya. Hanya saja dalam hal ini ketentuan sanksi dendanya dapat berbeda, menurut narasumber bagi pelaku akan dituntut denda ganti rugi dengan perbandingan berapa biaya yang dikeluarkan oleh pihak keluarga yang mengadakan acara Tiwah dulunya maka sebesar itu pula pelaku mengganti kerugian atas perbuatannya tersebut.

Diringankan atau diberatkan dendanya tergantung dari keputusan ketua adat yang mengadili perkara tersebut. Menurut beliau denda tersebut dikenakan mengingat nilai sejarah pada benda Patung Sapundu tersebut, adanya patung Sapundu ini karena melalui prosesi acara adat Tiwah yang merupakan satu kesatuan dengan Sandung dan barang adat dalam acara Tiwah lainnya.

\section{SIMPULAN DAN SARAN}

Perlindungan dari KUHP

khususnya dalam Pasal 363 tersebut sifatnya berbentuk preventif dan represif. Undang- undang Republik Indonesia Nomor 11 Tahun 2010 tentang Cagar Budaya, Pasal 26,27,28 dan 66. Sanksi Adat bagi perbuatan mencuri tersebut dapat dikenakan Singer (denda), yaitu: Singer rampas takau luar huma (denda adat curi- rampas barang di luar rumah), dengan penjelasannya: Barang milik orang di luar rumah hilang di curi orang lain, pemiliknya memberitahukan kehilangan itu kepada Ketua Adat setempat, walaupun waktu itu tidak diketahui siapa yang berbuat, tetapi kemudian diketahui hal ini langsung dituntut. Sanksinya: Pencuri diancam hukuman 15-30 kati ramu (barang adat), dapat ditambah kalau nilai barang itu tinggi dan sisa barang itu sengaja dirusaki. Dapat diringankan kalau barang itu dikembalikan sebagian atau seluruhnya dalam keadaan baik, ditutup dengan pesta adat yang ditanggung oleh pihak pencuri.

\section{DAFTAR PUSTAKA}

Djulianto, S. (2016). Arkeolog Jakarta, Berbagai Kejahatan Terhadap Peninggalan Arkeologi.

Elbaar, L., Ahmad, A., \& Bahen, T. J. (1982). Ceritera Rakyat Daerah Kalimantan Tengah. Direktorat Jenderal Kebudayaan.

Faal, M. (1991). Penyaringan Perkara Pidana oleh Kepolisian (Discretion Kepolisian). Jakarta: PT Paradnya Paramitha.

Hanum, G. C. T. (2013). Perlindungan Hukum Terhadap Masyarakat Hukum Adat Di Indonesia Atas Pemanfaatan Sumber Daya Genetik Sebagai Suatu Kekayaan Intelektual. Universitas Diponegoro.

Hardiyanto, A. (2017). Upaya Dinas Kebudayaan,

Pariwisata,

Pemuda Dan Olahraga Dalam Melestarikan Kesenian

"Keling" Di Dusun Mojo Desa Singgahan Kecamatan Pulung Kabupaten Ponorogo.

Universitas Muhammadiyah Ponorogo.

Hartoyo, A. (2012). Eksplorasi Etnomatematika Pada Budaya Masyarakat Dayak Perbatasan Indonesia-Malaysia Kabupaten Sanggau Kalbar. Jurnal Penelitian Pendidikan, 13(1), 14-23.

Iban, C., \& Elfrida, T. (2017). Arsitektur Religi Pesta Tiwah Dayak Ngaju 
Sebagai Daya Tarik Wisata Budaya Di Kalimantan Tengah. ATRIUM Jurnal Arsitektur, 3(2), $101-112$.

Karmadi, A. D. (2007). Budaya lokal sebagai warisan budaya dan upaya pelestariannya. Makalah Disampaikan Pada Dialog Budaya Daerah Jawa Tengah. Semarang: Balai Pelestarian Sejarah Dan Nilai Tradisional Yogyakarta Dan Dinas Pendidikan Dan Kebudayaan Propinsi Jawa Tengah.

Lastaria, L., Ramdhani, M. T., \& Handayani, I. T. (2018). Makna Dan Fungsi Simbol Biologika menurut Budaya Masyarakat Dayak Ngaju di Museum Balanga Palangka Raya. Anterior Jurnal, 18(1), 64-70.

Lion, E. (2020). Makna Sepundu Bagi Masyarakat Agama Hindu Kaharingan Dalam Upacara Tiwah Di Desa Tumbang Manjul Kecamatan Seruyan Hulu Kabupaten Seruyan. Jurnal Paris Langkis, 1(1), 15-20.

Mohamad, S. (2010). Perlindungan Hukum Terhadap Benda Cagar Budaya Di Provinsi Gorontalo. Jurnal Legalitas, 3(2).

Mubarat, H., \& Junoko, S. (2020). Konsep dan Strategi Upaya Pelestarian Kerajinan Laker Palembang Melalu Pelatihan dan Workshop. Besaung: Jurnal Seni Desain Dan Budaya, 5(1).

Onibala, H. (2017). Pelatihan Pelestarian Benda Cagar Budaya Dalam Pengembangan Pariwisata Budaya Bagi Aparat Desa

Radey Dan Pakuweru Di Kecamatan Tenga Minahasa
Selatan. Edupreneur: Jurnal Pengabdian Kepada Masyarakat Bidang Kewirausahaan, 1(1).

Ramelan, W. D. (2016). Permasalahan Pengelolaan Cagar Budaya dan Kajian Manajemen Sumber Daya Arkeologi.

Safitrf, I. (2013). Kepercayaan Gaib Dan Kejawen Studi Kasus pada Masyarakat Pesisir Kabupaten Rembang Ikha Safitrf Perencanaan dan Pengelolaan Sumberdaya Kelautan Program Magister Manajemen Suniberdaya Pantai Universitas Diponegoro Abstract. Sabda: Jurnal Kajian Kebudayaan, 8(1), 18-28.

Sasmito, H. P., \& Hanif, M. (2014). Kehidupan Sosial Ekonomi Juru Pelihara Situs Cagar Budaya Di Madiun Tahun 2013. Agastya: Jurnal Sejarah Dan Pembelajarannya, 4(2), 33-53.

Soekanto, S. (1988). Penanggulangan pencurian kendaraan bermotor: suatu tinjauan kriminologis. Jakarta: Bina Aksara.

Suarta, I. M. (2013). Kearifan Lokal (Local Genius) Sebagai Soko Guru Menata Peradaban Bangsa Yang Berkarakter Nusantara (Refleksi Karya Ki Dalang Tangsub). Jurnal Ikadbudl, 2, 1-18.

Sutanto, A. (2014). Faktor-Faktor Keterbengkalaian Benteng Toboali Sebagai Bangunan Bersejarah. Jurnal Pembangunan Wilayah \& Kota, 10(1), 94-105.

Syamsuddin, M. (2018). Orang Madura Perantauan di Daerah Istimewa Yogyakarta. Aplikasia: Jurnal Aplikasi IImu-IImu Agama, 18(1), 1-22.

Usop, T. B. (2016). Membangun Jatidiri Pengembangan Potensi Arsitektur 
Dayak Kalimantan Tengah Dalam Harmonisasi Arsitektur Mendatang. Fakultas Teknik, Jurusan Arsitektur, Universitas Palangka Raya, Palangka Raya.

Utami, S. (2012). Sekilas Koleksi Museum Negeri Provinsi Kalimantan Tengah "Balanga", Bagian Proyek, Pembinaan Permuseuman Kalimantan Tengah.

Wirawan, K. (2009). Pelestarian Peninggalan Sejarah dan Purbakala. Bandung: PT.Citra Aditya Bakti.

Yulita, Y. (2012). Naskah Katalog Koleksi "Pesona Koleksi Hampatung Jendela Tradisi Suku Dayak di Kalimantan Tengah". Museum Balanga Provinsi Kalimantan Tengah.

Yunus, S. P. I., \& Fadli, H. S. (2020). Pluralisme dalam Bingkai Budaya:Bintang Pustaka. Jakarta: Bintang Pustaka Madani. 